\title{
Changing role of women in the Irish society: an overview of the female consumer
}

Ashling Sheehan, Elaine Berkery and Maria Lichrou*

Department of Management and Marketing, Kemmy Business School, University of Limerick, Ireland

Abstract: The changing role of women in the Irish society has attracted significant attention within the sociology literature; however, there has been little discussion within the field of marketing. This paper aimed to synthesise existing research and literature in the area to outline the key changes in the role of women in the Irish society since the 1920s, highlighting the impact of such changes on consumer behaviour patterns in Ireland. It specifically focused on key landmarks in the transformation of women in the Irish society, including the participation of women in the labour force, Ireland's economic growth since the mid-1990s and the current economic recession. These changes provide the backdrop for the emergence of female consumer patterns in Ireland, which were then discussed under the following themes: changing attitudes towards family life, representations of women in the media and the recession.

Keywords: female consumer; consumer behaviour; Irish society

(C) De Gruyter Open Sp. z 0.0 .

\section{INTRODUCTION}

The role of women in the Irish society has changed more dramatically in the twentieth century, in particular over the last three decades, than in any other period of Irish history, with the majority of these changes attributed to changes in the economic and labour structures of the country. In fact, one of the most dramatic changes in the Irish society has been the substantial increase in the number of women participating in the paid workforce and the concomitant change in gender roles (O'Sullivan, 2012). Traditionally, the Irish society has been strongly influenced by male patriarchal structures, with males having a strong influence over economic, legal, political and societal structures in Ireland, thus making gender crucial to understanding Irish society (O'Connor, 1998, 2000). According to O'Connor (1998), discussions on the role of women in the Irish society tend to elicit two contrasting views: (1) it has changed completely and (2) it has not changed at all. Those endorsing the first view note that the changes in the role of women in the Irish society can be attributed to the abolishment of wage scales and the 'marriage bar', the diminishing inequalities in the welfare system, the introduction of legal maternity leave and divorce and finally, the increase in extramarital births. On the other hand, those eliciting the opposing view argue that the role of women has not changed at all. Such advocates highlight that women remain under-represented in the political system, male dominance continues in the higher echelon of the economic system and the institutional church structure, lower wages scale remain in place for women, women remain confined to a small range of paid occupations and women continue to assume the main responsibility for domestic and childcare activities.

While many of these analyses and discussions have taken place within the sociology literature, there has been little by way of similar discussions within the context of the role of Irish women in the marketing and more specifically consumer behaviour literature. The aim of this paper was not to develop new theoretical perspectives on women as consumers in Ireland but to synthesise the literature up to 2014 and empirical data on Irish female consumers. In doing so, we wished to provide a research trajectory for researchers and a comprehensive view of the current context to practitioners. This research is particularly timely, given the changing role of women in the

\section{*E-mail: maria.lichrou@ul.ie}


society, workplace and home and given the paucity of research examining women as consumers in Ireland. There were a number of reasons for choosing to synthesise the existing research as opposed to collecting primary data for this paper: (1) it helps clarify what is already known in the area, identify gaps in the literature (Suri and Clarke, 2009) and highlight areas of further research, (2) it also helps justify the need for further research by highlighting to researchers and practitioners the relationship between societal changes in Ireland and the changing profile of consumers in the country and (3) it adds value to the existing research and data by shedding a new light and a different perspective on existing findings (Suri and Clarke, 2009).

\section{CHANGES IN THE ROLE OF WOMEN IN THE IRISH SOCIETY}

\section{Participation of women in the workforce}

For centuries, women in Ireland were bound by Ireland's traditional patriarchal society that confined them to their home and characterized them as one dimensional (Patterson, 2001). In the early decades of the new Irish state, Catholic ideology and constitutional developments combined to create a range of barriers, both formal and informal, to the participation of women, in particular married women, in the Irish workforce. With the alienation of women from the workforce, the role of motherhood became embedded as the 'natural' role for women both socially and legally in Ireland. Article 41.2.1 of the Irish constitution (Government of Ireland, 1937) stated that 'By their life within the home, women give to the State a support without which the common good cannot be achieved'. Furthermore, Article 41.2.2 indicated the state's active support of this role for women declaring that the State, shall, therefore, endeavour to ensure that mothers shall not be obliged by economic necessity to engage in labour to the neglect of their duties in the home'. Females were further restricted in the labour market as a result of numerous legislative measures employed in the early 1900s, for example: (1) the 1925 Civil Service Act, "...(2) a marriage bar introduced in the civil service in 1932 (O'Leary, 1987) and (3) restriction on the labour market participation of working-class women in 1935 following the introduction of the Conditions of Employment Act (O'Dowd, 1987). Such labour force restrictions left women with very little disposable income, leaving men with key purchasing decisions and power in the family home. Furthermore, the role of women in the Irish society remained firmly embedded within the home as a homemaker.

In 1944, the children's allowance scheme was introduced in Ireland (O'Donoghue, 2003). The primary aim of this scheme was not only to assist families with the cost of children but more importantly to provide an income to support mothers who had recently given birth to a child (Daly and Calvero, 2002), thus giving Irish mothers a form of financial independence at home. The 1960s and 1970s marked the beginning of Ireland's economic development, when the country moved from being a rural agriculture economy to an urbanised industrial economy. This period in the Irish history also marked the entrance of women into the workforce in greater numbers, changing the social, political and religious landscapes in Ireland. Since the 1970s, there was also a shift in legislation: (1) the marriage bar was lifted for all civil service employees in 1973, (2) the enactment of equal pay legislation in 1975 demolished the practice of paying women lower wages for work similar to that being carried out by their male colleagues, (3) in 1981, pregnant workers gained rights through the passing of the Maternity Protection of Employees Act and (4) the Employment Equality Act (1998) and Equal Status Act (2000) afforded more employment rights for women in the workplace. In addition, the Divorce Referendum was passed in 1995. Such legislative changes enabled women more freedom in the marketplace, affording them more rights and greater equality. This increased labour force participation rate increased the buying power of women in the Irish market place. The role of women in the Irish society also began to change with a dual role emerging for women as carer and worker. However, despite these emerging societal changes, the view of the family structure remained static (O'Connor, 1998).

Furthermore, the 1990s and early 2000s saw unprecedented growth in the Irish economy. Ireland went from been referred to as the 'poorest of the rich' by The Economist in 1988 to 'Europe's shining light' less than 10 years later. Female employment almost tripled in the 40-year period from 1966 to 2006 (from 289,144 to 822,808). For the majority of women, these changes have led to their role change from unpaid carers to dual role of carer and earners in the home. Employment growth in Ireland, as elsewhere in the EU, has been predominantly related to females in the last three decades. The country's changing democratic structure has meant an expanding labour force, which has, in turn, facilitated the increased participation of women in general and of married women and mothers in particular into the workforce. Female employment rates peaked in Ireland in 2007, when the rate of female employment stood at $60.7 \%$ compared to $77.6 \%$ for males. By 2008 , Ireland had entered a severe recession, which 
saw a massive adjustment in Ireland's labour market. The employment rate (for those aged 15-64 years) in Ireland fell sharply between 2008 and 2012, from $69.1 \%$ to $59.1 \%$, before slightly increasing in 2013 and 2014 . The male employment rate during this period fell sharply from $76 \%$ in 2008 to $62.4 \%$ in 2012 before slightly increasing to $64.6 \%$ in 2013 . The female employment rate also declined during this period from $60.6 \%$ in 2008 to $55.2 \%$ in 2012 , also recording a slight increase to $55.9 \%$ in 2013. In 2012, Ireland's employment rate was the fifth lowest in the EU and its unemployment rate was the fifth highest in the EU. However, the effects of the current economic recession have been less detrimental on women than on men; employment rates for women stood at $56 \%$ in 2011 compared to $63.3 \%$ for men (CSO, 2011a,b). According to the results of the 2011 Irish Census, for the first time in employment history, female employees had surpassed that of men (O'Brien, 2012).

The increased numbers of women in higher paying jobs may also be attributed to the increased number of women in tertiary education. In the period of 1997-2005, the female participation rate in the third-level education overtook that of males. By 2003, the female proportion of entrants to Irish universities was 58\% (Fitzpatrick Associates and O Connell, 2005). More women aged 18-24 years had a third-level qualification than men, and this gap had been increased between 2004 and 2013 from 6.8 to $12.6 \%$ (CSO, 2013).

Women's high levels of participation in the workplace have focused attention on their changing socioeconomic status and consumer behaviour that has led to changes in lifestyles and consumption patterns (Mitchell, 1983).

\section{Changing attitudes towards family life}

The changing role of women in the Irish workforce has also had an impact on family life in Ireland. Galligan (1998) states that the changing role of women produces changes in the dependent female roles of wife, mother and homemaker, holding out the potential of greater sexual freedom and independence in a variety of contexts. The composition of the traditional family in Ireland has changed dramatically in the last three decades. Such changes can be attributed to declining fertility and family size, significant increases in non-marital births, increasing diversity in the family structure and a widening generation gap in the sexual practices of the population (Canavan, 2012). However, despite these changes, O'Connor (1998) suggested that many commentators continue to view Irish family structures as a static phenomenon. However, recent research had revealed the changing attitudes towards family life. Research carried out in 2011 revealed that $84 \%$ of Irish people believe that it is better to live with someone before you marry them; $85 \%$ of people feel that the religious reasons for marriage have become less important; $69 \%$ of people think that while marriage provides a solid family unit, cohabiting does too; $69 \%$ think that deciding to have a child together would be a far greater commitment than getting married and $49 \%$ of respondents had cohabited at least once (Fine-Davis, 2011). Another changing attitude of Irish women is that more than $90 \%$ of them think that people should be allowed to remarry if their first marriage fails (The Independent, 2010). Therefore, the changing behaviour and beliefs of the Irish family structure have social implications on Irish women and have influenced their consumer behaviour as the family dynamics change.

Almost one in three families in Ireland departs from the traditional family model (a married couple both of whom are in their first marriage), and one in four children younger than 21 years lives in a family that does not conform to this model (Lunn and Fahey, 2011). The research also found that there is an increasing acceptance of same sex relationships; lone parents and cohabiting are also notable changes in Ireland. Another report (Fine-Davis, 2011) discovered that $11 \%$ of Irish families involve cohabiting couples. The report also found that $58 \%$ of these couples had no children. Additionally, the report found that $87 \%$ of lone-parent families were headed by mothers, with two-fifths of lone parents being single and just less than one-quarter widowed. Furthermore, the study found that $31.8 \%$ of lone parents were separated or divorced, an increase from $29.8 \%$ in 2006 . The study also depicted that there were 4,042 same-sex couples living together in Ireland, with 2,321 being males and 1,721 being females; approximately 230 same-sex couples had children, the vast majority of whom were women.

The changes in the family structure have also influenced the landscape of the profile of women in the Irish workforce. Considering the 10-year period from 1998 to 2008 (Russell et al., 2009), the participation rate for married women increased year on year $(43.3 \%$ to $54.2 \%)$, a trend which was also evident among other female categories such as single females (55.5\% in 1998 to $61 \%$ in 2008$)$, separated or divorced females $(54.5 \%$ in 1998 to $61 \%$ in 2008), widows (8.8\% in 1998 to $12.3 \%$ in 2008) and mothers in employment with a husband/partner (increased by $32 \%$ from 271,500 in 2001 to 359,100 in 2008). Furthermore, in recent years, choices and possibilities regarding family formation and its timing and child-rearing practices are strongly connected to labour force increased decisions (Canavan, 2012). An important trend is delayed fertility. Signs that increasing numbers of Irish mothers are delaying childbirth until later in life were confirmed in the 2006 census figures and had been reported in the Irish media (The 
Irish Times, 2012). The average age of women at the birth of first child had increased from 27.5 years in 1955 to 29.4 in 2010 (CSO, 2011a,b). According to Linehan (2008), Irish women have more disposable income to spend on recreational products, services or activities when delaying starting a family. Thus, they embrace a self-identity as independent, economically active women. She also conducted a research that depicted that the most valued goal for Irish women was financial independence. Younger women in particular tend to spend the most on themselves, while the cost of rent, mortgage and family expenses places additional financial problems on those aged 35 years or older (Linehan, 2008). As women advance in the workplace in Ireland, they may delay the age of marriage and child-rearing.

Family status has also proven to impact on consumer behaviour patterns in the marketplace. Ultimately, once a woman starts a family, she obtains a time-pressed lifestyle, an emotionally demanding one often marked by experiences of guilt, frustration and feelings of being overwhelm by the juggling of different roles (Thompson, 1996). Studies had depicted that the gender division of domestic work has not changed significantly as women spend substantially more time on caring and household chores (McGinnity and Russell, 2008). Nearly all those looking after the home or the family in 2013 were women (CSO, 2013). Thus, gender stereotypes are still very dominant in the household. Most women are expected to maintain the family and household, therefore, maintaining responsibility for domestic chores such as shopping. Despite Irish women being more economically active, there is a time constraint due to the various roles they must fulfil. Women generally must reduce their time spent in household chores when they have a paid job (McGinnity and Russell, 2008). The increased pressure from combining a career and a family leaves less time for many activities, and this increases the importance of products and services that save time, such as microwaveable dinners, housekeeping services, childcare, fast food and food delivery services (Linehan, 2008). Price becomes less important than convenience, availability, service and time saving (Mitchell, 1983). Furthermore, Irish women are not readily accessible through traditional media (Linehan, 2008) as they once were as working women do not have as much time to watch television or listen to the radio; thus, many companies use direct marketing techniques or Internet sites to target women. $\mathrm{A}$ recent trend forming in Ireland is home shopping, where consumers can buy goods and services from home, e.g. Tesco provide this service in Ireland. Thus, this service may be helpful for working Irish females, as it saves time and money.

\section{Economic growth and the development of a consumer society}

Following a period of stagnation in the 1970s and 1980s, economic growth rates in Ireland improved dramatically in the 1990s and early 2000s (Breathnach, 1998). Such changes were among the most rapid in the world (Ó Riain, 2000). During this period, Ireland reached the highest rate of employment growth and the highest employment rate in the history of the state (Ó Riain, 2000). The Irish gross domestic product increased dramatically, and in the mid-1990s (Leeflang and Van Raaij, 1995), the first signs of increased consumer optimism were noted. This resulted in positive consumer expectations and confidence in the economic development of the country and led to more discretionary expenditure (Leeflang and Van Raaij, 1995). As a result, consumer buying power and the general standard of living increased, giving rise to an increased spending on personal consumption. Ireland experienced a strong and rising level of aggregate demand, increasing overall household consumption between 1993 and 1999. The dramatic rise in the national income and spending on personal consumption during the 1990s strengthened domestic demand for all kinds of Irish-produced consumer goods (McCoy et al., 2001); for example, during this period, the number of cars registered in Ireland increased by $40 \%$ (Powell, 2003).

Although consumer subjectivity has been developing throughout the late nineteenth and twentieth centuries (Dolan, 2009), the rapid transition from scarcity to affluence that became evident since the mid-1990s accelerated the shift away from 'traditional' consumption. This involves the following phenomena:: the level of consumption growing considerably above the subsistence level; goods and services obtained mainly by acquisition rather than by household consumption and individuals judging others on the basis of their consumption level and style (Linehan, 2008). Each person chooses products, services and activities that help define a unique lifestyle; thus, lifestyle refers to a pattern of consumption reflecting a person's choice of how he or she spends time and money and is more than the allocation of discretionary income (Linehan, 2008). The overlap between occupational class and lifestyle appears to be very strong (Tomlinson, 2007).

This is a symptom of what has been termed a consumer culture; the significance of consumption is elevated so that individual (and collective) identity is negotiated through the consumption of material possessions and brands (Elliott, 1997; Holt, 1997) as individuals use consumption in order to construct and communicate their 
identities (Belk, 1988; Cherrier, 2009; Dittmar, 2007; Elliott and Wattanasuwan, 1998; Holt, 2002). The effects of consumer culture on the individual are seen simultaneously as liberating, because individuals are seen as independent, active agents engaging in diverse identity projects (Firat and Venkatesh, 1995), and devastating, because individuals experience alienation (Cova, 1997), lack of a coherent sense of self (Karanika and Hogg, 2010) and increased anxiety during role transitions (VOICE Group, 2010). In the case of women in particular, VOICE Group (2010) showed how consumption plays both a positive and a problematic, complicating role during transition into motherhood.

\section{Media representations}

Evidence to date also highlights the under- and misrepresentation of women within the advertising industry in Ireland through various media forms. Luo and Hao (2007) found that women are often under-represented or stereotypically portrayed as playing passive, submissive and dependent roles in the media and advertising industry. Irish advertisers are accused of utilising inappropriate and degrading stereotypes (Patterson et al., 2009). Gross (2009) highlighted that women are rarely featured in the media as narrators of their own experience or as authoritative sources, and if they are, they are featured in stereotypical roles. A substantial gap remains in the knowledge regarding the processes of the representations of women in advertising and the implications of such representations (Patterson et al., 2009). For instance, a study conducted by iReach Market Research (2011) discovered that $41 \%$ of Irish women across all purchase categories feel that advertisers do not understand them and this figure is higher among investment $(54 \%)$, automotive $(44 \%)$, and healthcare $(43 \%)$ advertisers and lower (38\%) among food advertisers. These figures suggest that marketing companies are failing to connect with many affluent Irish women who represent the largest market, considering their significant impact on consumer behaviour in Ireland due to their advanced status. Thus, most marketing companies are slow to react to the growth in women's influence on consumer behaviour patterns.

When used correctly, Patterson et al. (2009) argued that the use of advertising can be a positive force in Irish women's lives. They referred to Unilever's 'Campaign for Real Beauty' for its Dove brand, which showed that positive representation of women in advertising is possible, compelling and commercially advantageous. This campaign could be considered as a positive representation of Irish women, as it promotes positive body perception in women and also focuses on women as a target audience. A positive representation of women in the media may achieve a better relationship between marketers and women, which is vital considering that women make the majority of consumption decisions in Irish households. Interestingly, the study conducted by Patterson et al. (2009) refers to the National Women's Strategy 2007-2016, which is making an effort to tackle the issue of how women are represented in advertising in Ireland, ensuring equality for Irish women. This action will have an impact on the consumption of Irish women, as advertising has an influence on consumer behaviour. Their study contributes to the understanding of the role of advertising in consumption as they found that emotional response of consumer behaviour is the variable that results into strong association with the consumer behaviour.

\section{Economic recession}

Consumer culture in Ireland has also borne the brunt of the recent recession. Irish citizens 'witnessed a move from the historical epoch of the Celtic Tiger in 1995-2007, where consumption was at unprecedented high, to that of the Austerity epoch which began in 2007, and which had significant impact on the consumption experiences and practices of Irish citizens' (Prothero and McDonagh, 2014: 135). The pre-financial crisis period was generally characterised by hedonic, conspicuous consumption and high levels of materialism (Hamilton and Denniss, 2005). During the economic crisis, many consumers engage in 'austere consumption', which involves not only simplicity (Voinea and Filip, 2011) and reduction in spending on non-essentials but also a re-evaluation of the role consumption plays in the contemporary Irish society (Prothero and McDonagh, 2014). Consumer personality characteristics such as risk aversion, value consciousness and materialism are significantly affected due to budget constraints (Ang, 2000). Furthermore, a financial crisis has a significant impact on household functions. Common responses to economic shocks involve reducing consumption (including the quantity and quality of food, healthcare expenditures and investment in children's education), drawing on household savings and selling assets (Skoufias, 2003). Studies conducted suggest that consumption falls roughly half as much as the expected decline in income (Parker, 1999). When faced with financial difficulties, families are forced to restrain their personal needs and desires to adapt to the financial stringency of their condition (Kochuyt, 2004). In the 
study of Kochuyt (2004), although financially constraint, parents would rather neglect their own basic needs in order to satisfy their children's desires.

The financial struggles of Irish families received considerable media attention. A study carried out by the credit union indicated that half the country feels that they are just 'living to work', with $41 \%$ believing that there is no longer a future for them or their family in Ireland (The Irish Examiner, 2011). In addition, a report found that in a household with two adults and two children with both adults working, the minimum expenditure required to achieve a basic standard of living was approximately $€ 540$ per week and the figure would be higher if the children were in secondary school (The Irish Times, 2012).

Economic data documents show a decline in consumer spending during the years 2009-2013 (Duffy et al., 2014; Durkan et al., 2011). In particular, expenditure on cars and furniture significantly dropped in 2009, when the effects of the economic crisis were prominent (Durkan and O'Sullivan, 2011). Expenditure on electrical goods fell considerably less, but this could be due to the huge decline (33.3\%) in the prices of electrical goods, while in other consumer goods, price drop were less. Following a period of declining rates in the years 2010-2013, sales volume and value increased in 2014 (CSO, 2015). Households in 2009 may have maintained consumption levels, but some highly elastic expenditure heads, such as holidays abroad, experienced further decline (Durkan and O'Sullivan, 2011). Younger households were affected the most from the economic recession. Drawing on data from the national household survey, Gerlack-Kristen (2013) documents a large drop in the income of younger average households (younger than 45 years). She noted that between the 2004/2005 survey and 2009/10 survey, younger households' real disposable income decreased by $14 \%$ and real consumption including housing by $25 \%$ and excluding housing by $32 \%$ (Gerlach-Kristen, 2013).

It does not come as a surprise that the recession period also witnessed the rise of the budget supermarkets. In 2011, price was the number one determining factor in deciding where to carry out grocery shopping (National Consumer Agency, 2011). Consumers' appreciation of low prices was also reflected in the words of Martin Kelleher, managing director at food retailers SuperValu and Centra, who stated that SuperValu's price reductions and offers were set to top $€ 260$ million in 2011 (Hardie, 2011). He also affirmed that it has delivered cost savings for customers through a combination of increased promotions, meal deals and own brand to adapt to the changing consumer needs. These cost saving measures helped Irish women deal with the budget constraints in household expenditure during the financial crisis.

On the other hand, consumers develop behavioural patterns that stem from an emotional response towards the crisis (Quelch and Jocz, 2009). It is notable that a growth in the beauty sector was also documented during the recession, as the number of Irish women visiting beauty salons rose from 760,000 in 2008 to 830,000 in 2011 and women spending on cosmetics reached an average of $€ 14$ per month in 2011 (deBurca Butler, 2012 ). Thus, Irish women have continued if not increased their consumption of beauty products despite financial troubles. Women often find emotional fulfilment in the act of buying goods or services, while men seek to demonstrate their expertise or ability to procure status items (Solomon, 2003). Women were also found to be more likely than men to purchase things they did not intent to buy (Segal and Podoshen, 2013). Interestingly, The Economist (2012) stated that companies that were affected by the recession were targeting women consumers in order to boost sales. Women are thought to drive the world economy (Silverstein and Sayre, 2009).

If empowered, women could potentially become a powerful source for change in the Irish marketplace. The gender equality index shows that Ireland rates highly in the domains of 'work' and 'money' but scores significantly lower when it comes to 'power' (CSO, 2013). Furthermore, unemployment trends during the financial crisis had shifted and male unemployment rates in Europe grew higher than the corresponding female rates (Eurostat, 2015). In Ireland, the male rate of unemployment rose from $5 \%$ in 2003 to $15.9 \%$ in 2013 , while the female rate of unemployment rose from $4.2 \%$ to $11.4 \%$ over the same time period $(C S O, 2013)$. This may be due to the impact of the economic crisis in the construction industry. Given the high unemployment figures for men, many Irish women are now the breadwinners in a household (The Irish Times, 2011). In 2011, approximately 33\% of Irish women were the family's main breadwinners, a 20-fold rise since 1969 (The Independent, 2011). It is important to note, however, that the income inequality between women and men persists (Keane et al., 2014) and a higher percentage of women (53\%) are at risk of poverty compared to men (48\%) according to CSO (2013). Women thus have to make complex life cycle choices while taking account of uncertainty in a rigorous way (Browning and Crossley, 2001). Marketing should take on an increased role in maintaining the link between consumer and organisation and realigning the organisation's offerings with the changing marketplace, reconciling consumers' fears offering them comfort and addressing their need for value (O'Malley et al., 2011). 


\section{CONCLUSION}

Responding to the need for exploration of the Irish female consumer in light of the dramatic developments taking place in the Irish society, this paper drew a broad picture of the changes that are affecting Irish women and are shaping them as consumers. In so doing, we specifically examined participation in the labour force, changing attitudes towards family life, media representation, the economic environment and consumer culture. These are familiar themes, as they are often at the heart of sociological, political and everyday discourse. However, the dialogue is far less developed within marketing and consumer research in the Irish context. This overview contributes to this discourse, by opening up and extending the discussion within the discipline and by highlighting important dimensions that are of interest to academics and practitioners and propose areas for further research.

The evidence presented to date highlights the dramatic change in the role of women in the past century in Ireland, which has seen women evolve from a passive homemaker to a dual worker in both the home and labour market. Currently, women have begun to exert greater influence on spending decisions at home and have the ability to make key strategic spending decisions with their own salaries. Furthermore, the interactions between consumer culture and the Irish economy, moving from the period of Celtic Tiger to austerity, also complicate the dynamics in the marketplace and women's roles in it.

Further research should examine the changing identity of Irish female consumers and the role of consumption in the construction and negotiation of their identity positions. As Irish women move away from traditional forms of identity, their consumption decisions inform the construction and communication of different senses of self, including more active, independent and sexually freer selves. In taking on these new identity positions, they may also experience conflicts (e.g. Karanika and Hogg, 2010) and anxiety (e.g. VOICE Group, 2010). The way marketers respond through branding and communication of messages can play a positive or a problematic role (e.g. Thomsen and Sørensen, 2006). For example, in the context of advertising in Ireland, women are often portrayed in stereotypical roles, such as mothers, homemakers and sex objects. In addition, lack of resources, such as energy, health or money can make consumption a problem in negotiating role transitions (VOICE Group, 2010). There is also a need to see how men are negotiating these changes and the impact on their own identities and consumption practices. For example, research from the US had shown how at home fathers capitalise on certain consumption practices that build greater cultural legitimacy for their marginalised identity (Coskuner-Balli and Thompson, 2013).

The changing attitudes of Irish women distinguish younger generations of women as consumers from their mothers and grandmothers. This opens up the research agenda for examination of the intergenerational dynamics that shape their behaviours. Marketing has had a strong interest in intergenerational transmission of consumer behaviours, attitudes and values, which are seen as vital in long-term brand value and consumer socialisation (Davies et al., 2013). However, a cutting-edge research drawing on three generations of British women revealed how consumer behaviour within the family is shaped by intergenerational continuities and discontinuities (Davies and Fitchett, 2015). The research demonstrated how family identities are formed through negotiated efforts, everyday consumption practices and retail innovations (Davies and Fitchett, 2015). Considering the rapid and dramatic changes taking place in the Irish environment, research into the intergenerational dynamics that are shaping consumer behaviour can provide useful insights to academics and marketing practitioners alike.

This paper synthesised the changes in the role of women in the Irish society, linking these changes to changes in consumer behaviour in Ireland. This illuminated the complex role of women in the changing Irish society and economy and the positive and negative influences that shape their behaviour as consumers. These themes also highlighted the opportunities and challenges in the marketplace for practices that can enhance or further complicate female consumers' roles and identities. It is now time for researchers and practitioners to recognise these opportunities and challenges and pursue further research in this area to ensure that female consumers do not become undervalued and under-represented in the Irish marketplace. 


\section{References}

Ang, S. (2000). 'Personality Influences on Consumption'. Journal of International Consumer Marketing, 13: 1, 5-20.

Belk, R.W. (1988). 'Possessions and the extended self'. Journal of Consumer Research, 15(2), 139-168.

Breathnach, P. (1998). 'Exploring the 'Celtic Tiger' phenomenon causes and consequences of Ireland's economic miracle'. European Urban and Regional Studies, 5: 4, 305-316.

Browning, M. and Crossley, T. (2001). 'The life cycle of consumption and saving'. The Journal of Economic Perspectives, 15: 3, 3-22.

Canavan, J. (2012). 'Family and family change in Ireland: An overview'. Journal of Family Issues, 33: 10, 10-28.

Central Statistics Office (CSO). (2011a). Quarterly National Household Survey. http://www.cso.ie/en/ media/csoie/releasespublications/documents/ education/2011/educationalattainment2011.pdf [Accessed 25 July 2012].

Central Statistics Office (CSO). (2011b). Women and Men in Ireland, Dublin, Ireland: Stationery Office.

Central Statistics Office (CSO). (2013). Women and Men in Ireland, Dublin, Ireland: Stationery Office.

Central Statistics Office (CSO). (2015). Retail Sales Index February 2015, Dublin, Ireland: CSO Statistical Release:

Cherrier, H. (2009). 'Anti-consumption discourses and consumer-resistant identities'. Journal of Business Research, 62: 2, 181-190.

Coskuner-Balli, G. and Thompson, C.J. (2013). 'The status costs of subordinate cultural capital: At-home fathers' collective pursuit of cultural legitimacy through capitalizing consumption practices'. Journal of Consumer Research, 40: 1, 19-41.

Cova, B. (1997). 'Community and consumption: Towards a definition of the 'linking value' of product or services'. European Journal of Marketing, 31: 3/4, 297-316.

Daly, M., and Clavero, S. (2002). Contemporary family policy: A comparative review of Ireland, France, Germany, Sweden and the UK. Institute of Public Administration.

Davies, A. and Fitchett, J. (2015). 'In the family way: Bringing a mother-daughter (matrilineal) perspective to retail innovation and consumer culture'. Environment and Planning A Abstract, 47: 3, 727-743.

Davies, A., Fitchett, J. and Elliott, R. (2013). 'Marketing generations: Intergenerational aspects of consumer culture', in G. Cornelissen, E. Reutskaja and A. Valenzuela (eds), E - European Advances in Consumer Research, Vol. 10, Duluth, MN: Association for Consumer Research, pp.232-233.

deBurca Butler, J. (2012) 'Hair we go again', Irish Examiner, Wednesday, May 16, 2012. http:// www.irishexaminer.com/lifestyle/features/ humaninterest/hair-we-go-again-193980.html [Accessed 24 November 2017].

Dittmar, H. (2007). Consumer Culture, Identity and WellBeing: The Search for the 'Good Life' and the 'Body Perfect', Hove, England: Psychology Press.

Dolan, P. (2009). 'Developing consumer subjectivity in Ireland: 1900-80'. Journal of Consumer Culture, 9: 1, 117-141.

Duffy, D., McQuinn, K., Byrne, D. and Morley, C. (2014). Quarterly Economic Commentary, Winter 2014, Dublin: ESRI.

Durkan, J., Duffy, D. and O' Sullivan, C. (2011). 'Household Consumption', Quarterly Economic Commentary, Autumn 2011, Dublin: ESRI.

Economist. (2012). 'Marketing to Women: Hello, Girls', The Economist. http://www.economist.com/ node/13278440 [Accessed 14 September 2012].

Elliott, R. (1997). 'Existential consumption and irrational desire'. European Journal of Marketing, 31: 3/4, 285-296.

Elliott, R. and Wattanasuwan, K. (1998). 'Brands as symbolic resources for the construction of identity'. International Journal of Advertising, 17: 2, 131-144.

Employment Equality Act. 1998. In 21/1998. Ireland: Office of the Attorney General.

Equal Status Act. 2000, 2004. In 8/2000. Ireland: Office of the Attorney General.

Eurostat (2015). Unemployment Trends - Statistics Explained. http://epp.eurostat.ec.europa.eu/ statistics_explained/index.php/Unemployment_ trends [Accessed 2 April 2015].

Fine-Davis, M. (2011). Attitudes to Family Formation in Ireland: Findings from the Nationwide Study, Dublin: Trinity College Dublin.

Firat, A.F. and Venkatesh, A. (1995). 'Liberatory postmodernism and the reenchantment of consumption'. Journal of Consumer Research, 22: 3, 239-267.

Fitzpatrick Associates and O' Connell, P. J. (2005). A review of higher education participation in 2003, Dublin: The Higher Education Authority.

Galligan, Y. (1998) 'The changing role of women' in W. Crotty and D.E. Schmitt (eds), Ireland and the politics of change. New York, Longman, pp. 107121. 
Gerlach-Kristen, P. (2013). "Younger and Older Households in the Crisis," ESRI Research Note 2013/1/4, in Spring Quarterly Economic Commentary, Economic and Social Research Institute: Dublin.

Government of Ireland. (1937). Constitution of Ireland- Bunreacht na hÉireann. Office of the Houses of the Oireachtas. http://www. taoiseach.gov.ie/eng/Publications/Publications_ Archive/Publications_2012/Bunreacht_ na_h\%C3\%89ireann-Aug2012.pdf [Accessed 26 March 2012].

Gross, L. (2010). UN Chronicle - Invisible in the Media. https://unchronicle.un.org/article/invisible-media [Accessed 24 November 2017].

Hamilton, C. and Denniss, R. (2005). Affluenza: When too much is Never Enough, Sydney: Allen \& Unwin.

Hardie, C. (2011). 'How do you Solve a Problem Like Ireland?'. http://www.retail-week.com/ property/how-do-you-solve-a-problem-likeireland/5025292.article\# [Accessed 7 September 2012].

Holt, D.B. (1997). 'Poststructuralist lifestyle analysis: Conceptualizing the social patterning of consumption in postmodernity'. Journal of Consumer Research, 23: 4, 326-350.

Holt, D.B. (2002). 'Why do brands cause trouble? A dialectical theory of consumer culture and branding'. Journal of Consumer Research, 29: 1, 70-90.

iReach Market Research. (2011). Blog | iReach Market Research. http://www.ireachinsights.com/about/ blog/ [Accessed 25 July 2012].

National Consumer Agency (2011), Market Research Findings: Shopping and Pricing, Dublin: Competition and Consumer Protection Commission. https:// www.ccpc.ie/business/wp-content/uploads/ sites/3/2017/04/NCA-Market-Research-GroceryShopping-Pricing-Nov-2011.doc [Accessed: 24 November 2017].

Karanika, K. and Hogg, M.K. (2010). 'The interrelationship between desired and undesired selves and consumption: The case of Greek female consumers' experiences'. Journal of Marketing Management, 26: 11-12, 1091-1111.

Keane, C., Callan, T., Savage, M., Walsh, J.R. and Timoney, K. (2014). "Identifying Policy Impacts in the Crisis: Microsimulation Evidence on Tax and Welfare", Journal of the Statistical and Social Inquiry Society of Ireland, 42 (2012-13), 1-14.

Kochuyt, T. (2004). 'Giving away one's poverty. On the consumption of scarce resources within the family'. The Sociological Review, 52: 2, 139-161.
Leeflang, P.S.H. and Van Raaij, W.F. (1995). 'The changing consumer in the European Union: $A$ meta-analysis', International Journal of Research in Marketing, 12: 5, 373-387.

Linehan, M. (2008). Consumer Behaviour: Irish Patterns \& Perspectives, Dublin: Gill \& Macmillan Ltd, pp.1217.

Lunn, P. and Fahey. T. (2011). Households and Family Structures in Ireland, Dublin: ESRI.

Luo, Y. and Hao, X. 2007. 'Media portrayal of women and social change'. Feminist Media Studies, 7: 3, 281-298.

McCoy, D., Duffy, D., Hore, J. and MacCoille, C. (March, 2001). Quarterly Economic Commentary, Dublin: ESRI.

McGinnity, F. and Russell, H. (2008). Gender Inequalities in Time Use: The Distribution of Caring, Housework and Employment among Women and Men in Ireland, Dublin: Equality Authority; ESRI.

Mitchell, L. (1983). 'Changing Patterns in Consumer Behavior Engendered - by the Changing Status' of Women', The Southwestern Social Science Annual Meeting, Houston, TX.

O' Brien, C. (2012) 'Number of women employees exceeds men, census reveals', The Irish Times Friday, June 29, 2012. https://www.irishtimes.com/ news/number-of-women-employees-exceedsmen-census-reveals-1.1069359 [Accessed 10 October 2012]

Ó Riain, S. (2000). 'The flexible developmental state: globalization, information technology, and the 'Celtic tiger', Politics and Society, 28: 2, 157-193.

O'Connor, P. (1998). Emerging voices: Women in contemporary Irish society, Dublin: Institute of Public Administration.

O'Connor, P. (2000). 'Ireland: A man's world'. The Economic and Social Review, 31: 1, 81-102.

O'Malley, L., Story, V. and O'Sullivan, V. (2011). 'Marketing in a recession: Retrench or invest?'. Journal of Strategic Marketing, 19: 3, 285-310.

O'Sullivan, S. (2012). 'All changed, changed utterly'? Gender role attitudes and the feminisation of the Irish labour force'. Women's Studies International Forum, 35: 4, 223-232.

O'Donoghue, C. (2003). Redistributive Forces of the Irish Tax-Benefit System (No. 0072). National University of Ireland Galway, Department of Economics.

O'Dowd, L, 1987, "Church, state and women: The aftermath of partition", in Gender in Irish Society Eds Curtin, C, Jackson, P, O'Connor, B (Galway University Press, Galway) pp 3-36.

O'Leary, E. (1987). The Irish National Teachers' Organisation and the Marriage Bar for Women 
National Teachers, 1933-1958. Saothar, 12, 47-52.

Parker, J.A. (1999). The reaction of household consumption to predictable changes in social security taxes. The American Economic Review, 89(4), 959-973.

Patterson, M., O'Malley, L. and Story, V (2009). 'Women in advertising: Representations, repercussions, responses'. Irish Marketing Review, 20: 1, 9-22.

Patterson, R. (2001). 'Women of Ireland: Change toward social and political equality in the 21 st Century Irish Republic'. Perspectives on Business \& Economics, 19: 1-19.

Powell, B. (2003). 'Economic freedom and growth: The case of the Celtic tiger'. Cato Journal, 22: 3, 431448.

Prothero, A. and McDonagh, P. (2014). 'Consuming austerity: Visual representations', John W. Schouten, Diane M. Martin , Russell Belk (eds.) Consumer Culture Theory (Research in Consumer Behavior, Volume 16), Emerald Group Publishing Limited, pp.133-153.

Quelch, J.A. and Jocz, K.E. (2009). 'How to Market in a Downturn', Harvard Business Review, April. pp.111.

Russell, H., McGinnity, F., Callan, T. and Keane, C. (2009). A Woman's Place-Female Participation in the Irish Labour Market, Dublin: The Equality Authority.

Segal, B. and Podoshen, J.S. (2013). 'An examination of materialism, conspicuous consumption and gender differences'. International Journal of Consumer Studies, 37: 2, 189-198.

Silverstein, M.J. and Sayre, K. (2009). 'The female economy'. Harvard Business Review, 87: 9, 46-53.

Skoufias, E. (2003). 'Economic crises and natural disasters: Coping strategies and policy implications'. World Development, 31: 7, 10871103.

Solomon, M. (2003). Consumer Behavior, 3rd edn., New Jersey: Pearson Education.

Suri, H. and Clarke, D. (2009). 'Advancements in research synthesis methods: From a methodologically inclusive perspective'. Review of Educational Research, 79: 1, 395-430.

Tomlinson, M. (2007). 'Graduate employability and student attitudes and orientations to the labour market', Journal of Education and Work, 20(4), 285-304.

The Independent. (2010). 'Survey Reveals Changing Attitudes of Catholic Women'. http://www. independent.ie/national-news/survey-revealschanging-attitudes-of-catholic-women-2072724. html. [Accessed 23 August 12].

The Independent. (2011). Working Mums: ,Being the breadwinner has brought us closer as a family' Mothers \& Babies, Lifestyle - Independent.ie. http:// www.independent.ie/lifestyle/parenting/workingmums-being-the-breadwinner-has-brought-uscloser-as-a-family-2915912.html [Accessed 27 August 2012].

The Irish Examiner. (2011). 'Credit Union Survey Highlights Financial Struggles', Irish Examiner. http://www.irishexaminer.com/breakingnews/ ireland/credit-union-survey-highlights-financialstruggles-547619.html [Accessed 27 July 2012].

The Irish Times. (2011). 'Banker, Barista - Breadwinner'. The Irish Times, Saturday, October 01 $2011 . \quad$ http://www.irishtimes.com/newspaper/ magazine/2011/1001/1224304827811.html [Accessed 27 August 2012].

The Irish Times. (2012). 'Low-Income Families ,Struggling", The Irish Times, Monday, February 06, 2012. http://www.irishtimes.com/newspaper/ breaking/2012/0206/breaking17.html [Accessed 27 July 2012].

Thompson, C.J. (1996). 'Caring consumers: Gendered consumption meanings and the juggling lifestyle'. Journal of Consumer Research, 22(4), 388-407.

Thomsen, T.U. and Sørensen, E. B. (2006). 'The first four-wheeled status symbol: Pram consumption as a vehicle for the construction of motherhood identity'. Journal of Marketing Management, 22: 9-10, 907-927.

VOICE Group. (2010). 'Buying into motherhood? Problematic consumption and ambivalence in transitional phases'. Consumption, Markets and Culture, 13: 4, 373-397.

Voinea, L. and Filip, A. (2011). 'Analyzing the main changes in new consumer buying behavior during economic crisis'. International Journal of Economic Practices and Theories, 1: 1, 14-19. 